Brit. J. vener. Dis. (1966), 42, 225.

\title{
IMMIGRATION AND VENEREAL DISEASE IN GREAT BRITAIN*†
}

\author{
BY \\ R. R. WILLCOX \\ St. Mary's Hospital, London, W.2
}

In making my Presidential Address during the year which represents the half-centenary of the organization of the Venereal Disease Service in this country, I share the disappointment of all members of the Society that the speaker originally chosen for tonight-Dr Thorstein Guthe of the World Health Organization-has been unable to attend, although we are delighted that he hopes to do so on some later occasion.

In replacing him at short notice tonight, I feel that the subject should be a broad one-if not international at least national in scope-and one with which in his absence he may be indirectly identified. The material I propose to present as a replacement for Dr Guthe is largely drawn from the long-term fruits of the seeds he fertilized some 15 years ago, namely from the data of the British Cooperative Clinical Group in the formation of which I had the privilege of playing some part.

My subject concerns a problem that has always been with us. Countries like our own and the United States of America have a tradition of absorbing immigrant groups, and the people of the British Isles have long participated in the process of emigration to other countries, often in considerable strength.

It is traditional to blame venereal diseases, particularly syphilis, on immigrants. Old words for syphilis include Morbus gallicus in this country and "seaman's jealousy" in ancient China (Guthe and Willcox, 1954). Even when the endemic forms of syphilis were rampant in Europe they were attributed to the foreigner (e.g. the sibbens of Scotland to Cromwell's troops; the radesyge of Norway to the crew of a Russian schooner; the Dithmarsh evil of Schleswig-Holstein to the Norwegian labourers (Lancereaux, 1868); and so on). Syphilis is usually said to be imported-seldom exported!

* Presidential Address to the Medical Society for the Study of Venereal Diseases, London, on April 29, 1966.

+ Some of this material was presented at the International Cooperation Year Symposium on Immigrants at the Ciba Foundation on December 6, 1965, and to the Research Club, St. Mary's Hospital, London, on January 5, 1966.
This is only one aspect of the problem, for the male immigrant, removed from the home influences which tended to limit promiscuity, is more prone to contract venereal infections than men of the same age group in the home population; the Algerians in Paris, the Puerto Ricans in New York, the Mexicans in California, and the West Indians and Asians in Great Britain are but a few examples.

It has been calculated that in England and Wales West Indians of both sexes have gonorrhoea rates more than nineteen times higher than those of British-born members of the same age groups (Willcox, 1963).

If venereal diseases largely concern the itinerant male, the female sources of infection are usually found in the native population. Even among female prostitutes in brothels, when they were more obviously defined than to-day, over 90 per cent. were drawn from the country in which the brothels were situated (Willcox, 1958).

One suspects, looking back through history, that the mutual attraction and fusion of interests between the local female population and the Flemish weavers, the Normans, the Danes and Saxons, members of continental courts and kingly retinues, were no less evident in bygone centuries than in our own lifetimc when we have Irish labourers, American and other troops stationed in Britain, Cypriots, Maltese, Poles, and other continental newcomers to our shores, and immigrant groups from more distant lands whose presence is made more obvious by the colour of their skin. In fact, as far back as 1583 , there were no less than 5,141 foreign labourers in London which then had a population of around 200,000 or less (Rasmussen, 1947); doubtless these men were then served by local girls, and the harlots in the brothels of Bankside and the stews of Southwark were predominantly English.

An accurate assessment of the present-day numbers of immigrants in the United Kingdom is difficult to obtain. Possibly (if the Irish are excluded), the West Indians, Indians, and Pakistanis 
are the most prominent groups, and the tempo of immigration has markedly increased since 1959 (Fig. 1). In the 6-year period 1955-61, no less than 227,700 West Indian immigrants were added to the home population and 99,050 from India and Pakistan; all other Commonwealth groups accounted for a net total of only 48,950 (Willcox, 1965). Some restriction came with the passing of the Immigration Act in 1963, but it is estimated that there are now approximately 850,000 coloured immigrants in Great Britain, of which some 450,000 are West Indians, 165,000 Indians, and 100,000 Pakistanis. They represent nearly 2 per cent. of the population and some 34 to 40 towns in Great Britain comprise their major settlements.

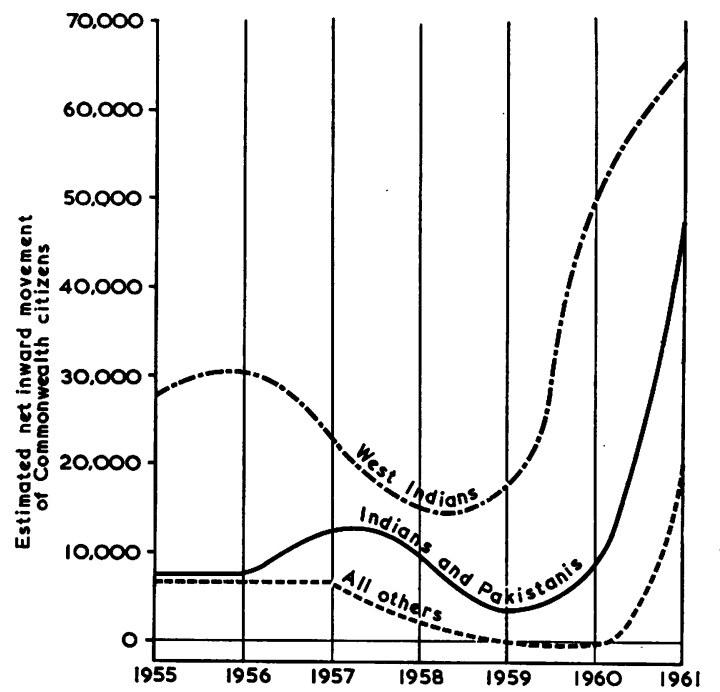

FIG. 1.-Estimated net inward movement of Commonwealth citizens into U.K., 1955-61.

Venereal diseases in Great Britain reached peak figures in 1945-6 by the end of the second world war, and many members of the lay public related this situation to certain groups of Allied forces in Britain at that time.

With the more settled conditions of peace and the availability of rapid effective treatment with penicillin, the numbers of cases, particularly of syphilis but also of gonorrhoea, fell markedly by the early and mid $1950 \mathrm{~s}$-so that some felt the venereal diseases had virtually been beaten. There has since been a rude awakening, the new cases of infectious syphilis being now, practically double the lowest total of 1957, although fortunately still only approximately one-thirteenth of peak total of 1946 (Ministry of Health, 1965). With gonorrhoea the situation is much worse; the numbers of new infections have more than doubled since 1954 and have now reached approximately 80 per cent. of the previous peak level. Indeed the present figures are comparable to those of pre-war and pre-antibiotic years. Once again the public have been quick to blame the immigrant groups.

However, this recrudescence in venereal diseases is a world-wide phenomenon. In the U.S.A., in the period 1957-64, cases of infectious syphilis increased 3.6 times and those of gonorrhoea by 34 per cent. (Joint Statement, 1965). In Europe increasing rates for early infections with syphilis compared with those for 1957 had been noted by 1962 in Belgium, Denmark, France, Sweden, and Yugoslavia, and an increasing incidence of gonorrhoea since 1957 was reported in Denmark, Finland, France, Luxembourg, Portugal, Sweden, and Turkey (WHO, 1964). The situation has since worsened further, and not all these countries (e.g. Denmark and Sweden) have significant immigrant problems.

It is necessary, therefore, that the contribution of immigrants to the current situation should be critically examined. Fortunately, a considerable amount of data is available concerning the country of origin of patients with venereal diseases, particularly gonorrhoea, from the studies of the British Cooperative Clinical Group (1956, 1960, 1962, 1963a, b, 1964, 1965a, b).

\section{Country of Origin of \\ Patients with Venereal Disease}

The latest published figures (1964) of the British Cooperative Clinical Group for England and Wales are shown in Table I and Fig. 2 (opposite).

TABLE I

COUNTRY OF ORIGIN OF PATIENTS WITH VENEREAL DISEASE IN 1964

Percentages: England and Wales only

\begin{tabular}{|c|c|c|c|c|}
\hline \multirow[t]{2}{*}{ Race } & \multicolumn{2}{|c|}{$\begin{array}{c}\text { Primary and Secondary } \\
\text { Syphilis }\end{array}$} & \multicolumn{2}{|c|}{ Gonorrhoea } \\
\hline & Male & Female & Male & Female \\
\hline $\begin{array}{l}\text { West Indians } \\
\text { Other Immigrants } \\
\text { U.K.-born }\end{array}$ & $\begin{array}{r}5.9 \\
33.5 \\
60.6\end{array}$ & $\begin{array}{r}9 \cdot 7 \\
11 \cdot 3 \\
79 \cdot 0\end{array}$ & $\begin{array}{l}22 \cdot 5 \\
27 \cdot 1 \\
50 \cdot 4\end{array}$ & $\begin{array}{r}8 \cdot 6 \\
8 \cdot 8 \\
82 \cdot 6\end{array}$ \\
\hline Total .. & $100 \cdot 0$ & $100 \cdot 0$ & $100 \cdot 0$ & $100 \cdot 0$ \\
\hline
\end{tabular}

Gonorrhoea.-Approximately one-half of infections in males occurred in those born in the United Kingdom and the remainder were in immigrant groups, of which West Indians (22.5 per cent.) formed the largest proportion. Of the other immigrant groups, Asiatics ( 8.4 per cent.) were next in importance, followed by those born in Eire (4.9 per cent.) and Europeans ( 4.2 per cent.); all other groups contributed 9.6 per cent. 


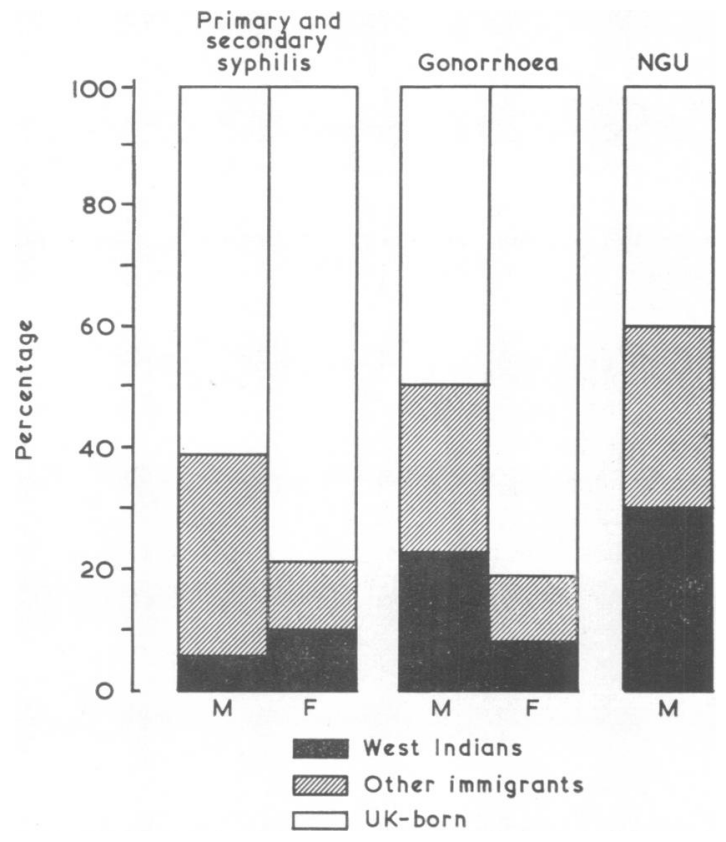

FIG. 2.-Country of origin of patients with infectious syphilis, gonorrhoea, and non-gonococcal urethritis.

On the other hand, more than four-fifths of infections in females occurred in those born in the United Kingdom and only $17 \cdot 4$ per cent. in immigrant women.

Primary and Secondary Syphilis.-Six out of ten infections in males were found in those born in the United Kingdom. West Indians (accounting for only 5.9 per cent. of infections) play a much less significant role in syphilis than in gonorrhoea. Asiatics (10.3 per cent.) were the most significant immigrant group, while Europeans accounted for 9.1 per cent., those born in Eire for $5 \cdot 3$ per cent., those born in the Mediterranean region for 4 per cent., and all other groups for $4 \cdot 8$ per cent.

Of females with primary and secondary syphilis (as with gonorrhoea) practically four-fifths were born in the United Kingdom.

Non-gonococcal Urethritis.-No national figures are available, but individual clinic figures, with immigrants accounting for 60 per cent. of infections (e.g. at St. Mary's), show the pattern more closely resembling that of gonorrhoea than that of syphilis (Willcox, 1965).

Scotland.-Here immigrants with venereal disease present a relatively insignificant problem. In 1965 in males 88.6 per cent. of infections with gonorrhoea and 88.7 per cent. of infections with primary and secondary syphilis occurred in men born in the United Kingdom (unpublished data).

\section{Trends in Immigrants}

Males.-The figures obtained by the British Cooperative Clinical Group, which for the past 4 years has achieved a coverage of 81-93 per cent. of the total cases of gonorrhoea in males in the clinics of England and Wales, have been used to estimate the total numbers of immigrants and others treated in these clinics (Table II and Fig. 3).

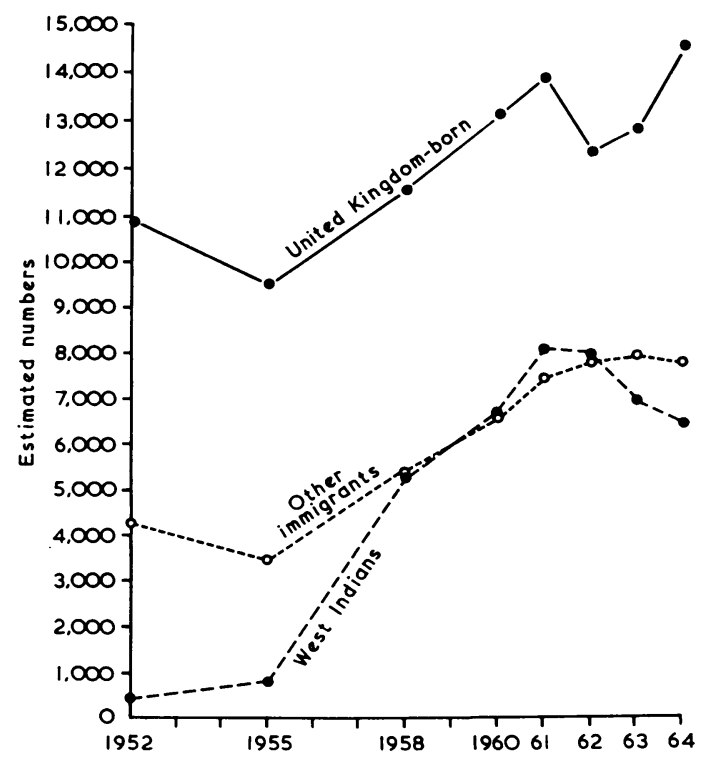

Fig. 3.-Estimated numbers of cases of gonorrhoea in males in the clinics of England and Wales, by racial origin, 1952-64.

The overall figures have more than doubled in the last decade and this increase is reflected in all three groups. The West Indians are by far the most significant single immigrant group and deserve separate consideration. Their numbers rose from an estimated 465 ( 3 per cent. of infections) in 1952 to a peak of 8,059 (28.3 per cent.) in 1961 , but since the passing of the Immigration Act, there has been

TABLE II

ESTIMATED NUMBERS OF CASES OF GONORRHOEA IN WEST INDIANS, OTHER IMMIGRANTS, AND UK-BORN MALES ENCOUNTERED IN CLINICS OF ENGLAND AND WALES

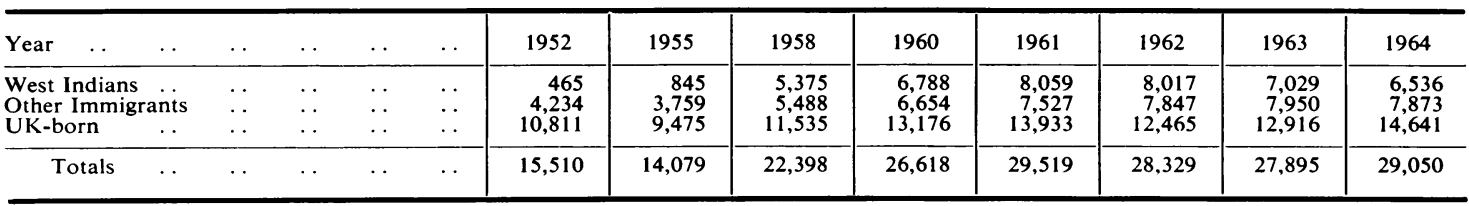


a significant decline to 6,536 cases $(22.5$ per cent.) in 1964 , and to only 20 per cent. in 1965 (unpublished data). Infections in other immigrants likewise increased significantly, although in 1963 and 1964, if there has been no fall in numbers, the rise seems at least to have been checked. The numbers of patients born in the United Kingdom, however, continues to rise (and this is expected to continue into 1965) even if the overall increase is proportionately less pronounced than among the immigrants. Thus, if there were no immigrants at all in England and Wales, there would still be a substantial increase in male cases of gonorrhoea (exceeding 50 per cent. between 1955 and 1964 for those born in the United Kingdom).

Asians form the most important group of immigrants other than West Indians (Table III and Fig. 4).

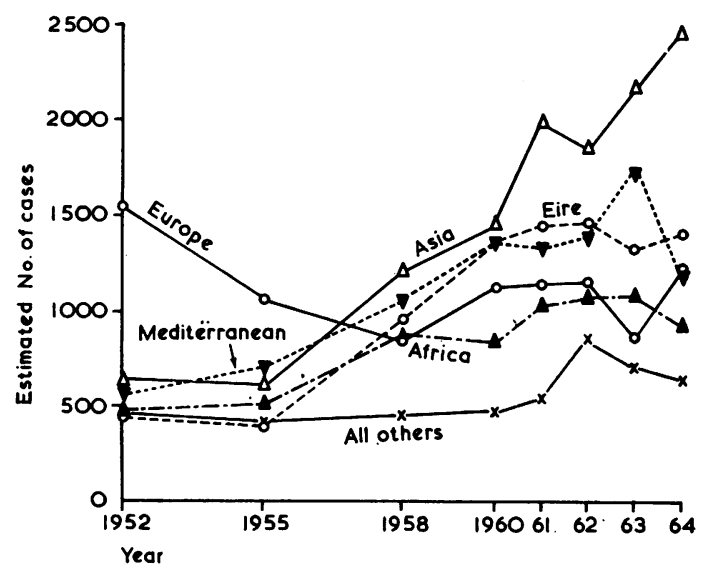

FIG. 4.-Estimated numbers of cases of gonorrhoea in male immigrants other than West Indians in England and Wales, 1952-64.

From 1952 to 1964 the number of Asians with gonorrhoea increased 3.6 times. The figure for Europeans, although showing a recent rise, decreased overall, but all the other groups showed an increase, particularly those born in Eire (3.1 times) compared with those from the Mediterranean region (2.0 times), African (1.9 times), and the rest (1.4 times). The rise in all groups, except Asians and Europeans, has changed to a fall in the most recent years, but gonorrhoea in Asians has now emerged as a significant problem.

The figures for 1965 are in process of preparation, but it can be stated that the proportion of Asians is the same ( 8.4 per cent.) as in 1964 , although there was still a small numerical increase. In regard to primary and secondary syphilis, the situation among Asians is much more alarming; they accounted for no less than 19 per cent. of infections in 1965 as against 10.3 per cent. in 1964 . This has resulted in a fall in the proportion of United Kingdom-born persons with syphilis which is not apparent with gonorrhoea.

Females.-The figures for gonorrhoea in females are shown in Fig. 5, and Table IV (opposite).

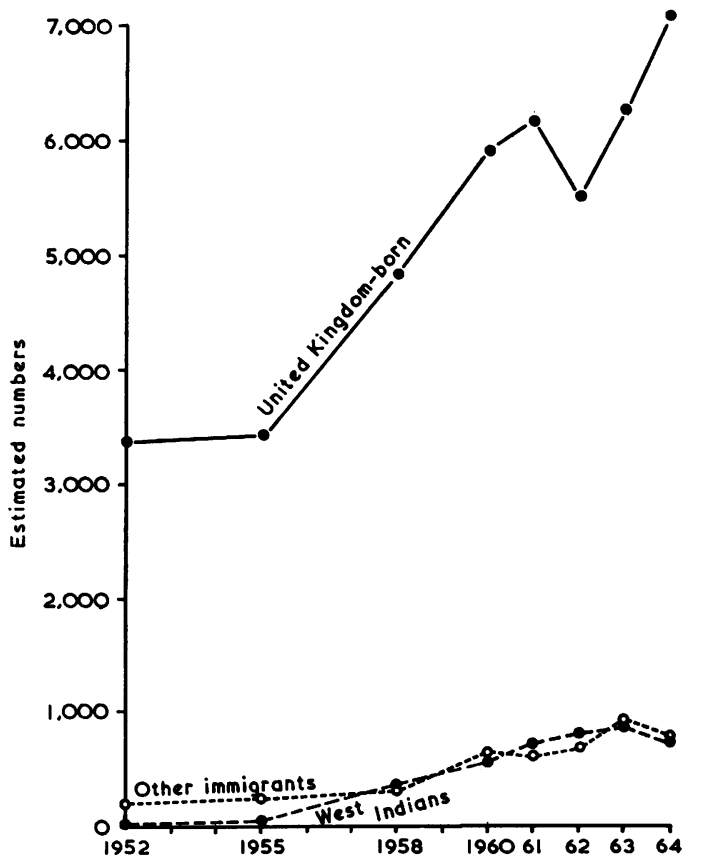

FIG. 5.-Estimated numbers of cases of gonorrhoea in females in the clinics of England and Wales, by racial origin, 1952-64.

TABLE III

ESTIMATED NUMBERS OF CASES OF GONORRHOEA IN OTHER IMMIGRANT MALES England and Wales Only, 1952-64

\begin{tabular}{|c|c|c|c|c|c|c|c|c|c|c|c|c|c|}
\hline \multicolumn{6}{|c|}{ Geographical Origin } & 1952 & 1955 & 1958 & 1960 & 1961 & 1962 & 1963 & 1964 \\
\hline $\begin{array}{l}\text { Asia ... } \\
\text { Mediterranean } \\
\text { Eire } \quad . . \\
\text { Europe .. } \\
\text { Africa . . } \\
\text { All Others }\end{array}$ & $\begin{array}{l}\cdots \\
\cdots \\
\cdots \\
\cdots\end{array}$ & $\begin{array}{l}\cdots \\
\cdots \\
\cdots \\
\cdots \\
\cdots\end{array}$ & $\begin{array}{l}\cdots \\
\cdots \\
\cdots \\
\cdots \\
\cdots\end{array}$ & $\begin{array}{l}\cdots \\
\cdots \\
\cdots \\
\cdots\end{array}$ & $\begin{array}{l}\cdots \\
\cdots \\
\cdots \\
\cdots\end{array}$ & $\begin{array}{r}667 \\
589 \\
450 \\
1,551 \\
496 \\
481\end{array}$ & $\begin{array}{r}648 \\
746 \\
380 \\
1,070 \\
507 \\
408\end{array}$ & $\begin{array}{r}1,210 \\
1,075 \\
986 \\
851 \\
896 \\
470\end{array}$ & \begin{tabular}{r|}
1,464 \\
1,357 \\
1,357 \\
1,145 \\
852 \\
479
\end{tabular} & $\begin{array}{r}2,007 \\
1,328 \\
1,446 \\
1,151 \\
1,033 \\
562\end{array}$ & $\begin{array}{r}1,870 \\
1,388 \\
1,473 \\
1,161 \\
1,077 \\
878\end{array}$ & $\begin{array}{r}2,176 \\
1,729 \\
1,339 \\
892 \\
1,088 \\
726\end{array}$ & $\begin{array}{r}2,440 \\
1,191 \\
1,424 \\
1,220 \\
930 \\
668\end{array}$ \\
\hline Totals & . & . & $\cdots$ & $\cdots$ & $\cdots$ & 4,234 & 3,759 & 5,488 & 6,654 & 7,527 & 7,847 & 7,950 & 7,873 \\
\hline
\end{tabular}


TABLE IV

ESTIMATED NUMBERS OF CASES OF GONORRHOEA IN IMMIGRANTS AND OTHER FEMALES ATTENDING THE CLINICS OF ENGLAND AND WALES

\begin{tabular}{|c|c|c|c|c|c|c|c|c|c|c|c|c|c|}
\hline Year $\ldots$ & . & $\cdots$ & . & .. & $\ldots$ & 1952 & 1955 & 1958 & 1960 & 1961 & 1962 & 1963 & 1964 \\
\hline $\begin{array}{l}\text { West Indians } \\
\text { Other Immigra } \\
\text { UK-born }\end{array}$ & ints & $\begin{array}{l}\cdots \\
\cdots \\
\cdots\end{array}$ & $\begin{array}{l}\ldots \\
\ldots \\
\ldots\end{array}$ & $\begin{array}{l}\cdots \\
\cdots \\
\cdots\end{array}$ & $\begin{array}{l}\ddot{ } \\
\cdots\end{array}$ & $\begin{array}{r}18 \\
172 \\
3,395\end{array}$ & $\begin{array}{r}41 \\
241 \\
3,484\end{array}$ & $\begin{array}{r}324 \\
296 \\
4,869\end{array}$ & $\begin{array}{r}565 \\
651 \\
5,936\end{array}$ & $\begin{array}{r}744 \\
622 \\
6,222\end{array}$ & $\begin{array}{r}832 \\
682 \\
5,595\end{array}$ & $\begin{array}{r}856 \\
946 \\
6,352\end{array}$ & $\begin{array}{r}741 \\
758 \\
7,116\end{array}$ \\
\hline Totals & $\ldots$ & . & . & . & . & 3,585 & 3,766 & 5,489 & 7,152 & 7,588 & 7,109 & 8,154 & 8,615 \\
\hline
\end{tabular}

From 1952 to 1964 the total number of gonococcal infections in females attending the clinics of England and Wales increased $2 \cdot 4$ times. The vast majority of infections occurred in women born in the United Kingdom and their numbers continue to rise. The number of West Indian females with gonorrhoea, insignificant in 1952-5 (with an estimated annual total of less than fifty in these years), increased to 856 by 1963 but fell significantly to 741 in 1964 . The figure for other female immigrants likewise reached a peak in 1963, but has also since fallen appreciably, so that infections in West Indian females and other female immigrants comprised only $17 \cdot 4$ per cent. of the total in 1964. Thus, if there were no immigrant

Males
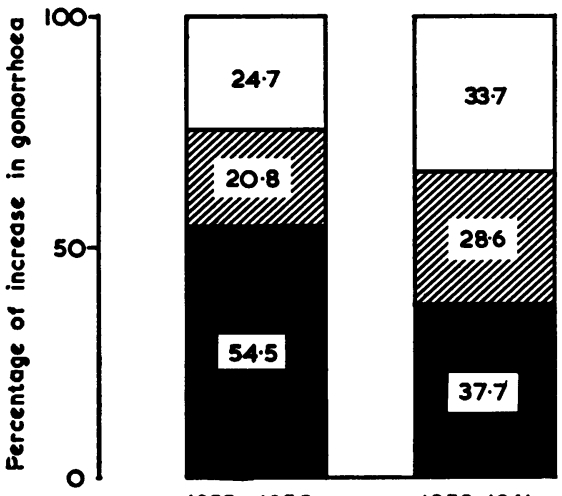

1955 - 1958

$1958-1961$

FiG. 6.-(A) Percentage of increase in cases of gonorrhoea in males due to immigrants. females, there would still be a most significant increase; the figures for United Kingdom-born females have more than doubled since 1955.

\section{Percentage of Increase accounted for by Immigrants}

Data may be considered in three 3-year periods: 1955-8, 1958-61, and 1961-4 (Table V).

Males (Fig. 6A)

1955-8.-Gonococcal infections rose from 14,079 to 22,398 (an increase of 59.1 per cent.). During this period of rapid expansion no less than $75 \cdot 3$ per cent. of the increase was accounted for by immigrants $(54.5 \mathrm{per}$

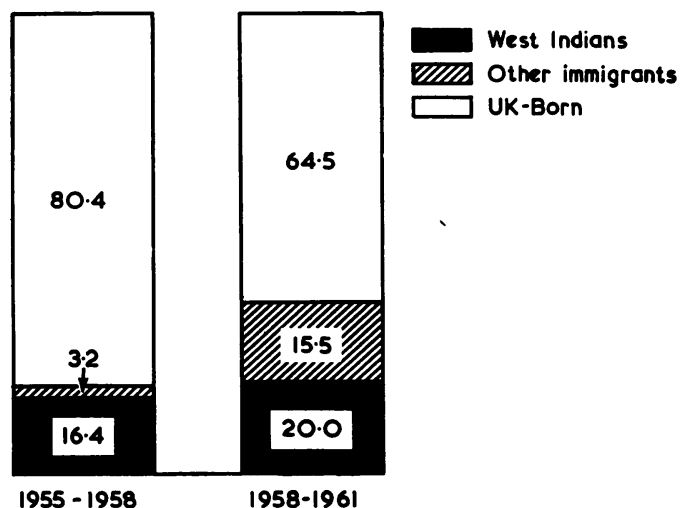

Fig. 6.-(B) Percentage of increase in cases of gonorrhoea in females due to immigrants.

TABLE V

PERCENTAGE OF INCREASE OF GONORRHOEA DUE TO IMMIGRANTS

\begin{tabular}{|c|c|c|c|c|c|c|}
\hline Sex & Race & & & 1955-8 & $1958-61$ & $1961-4$ \\
\hline \multirow[t]{2}{*}{ Male } & $\begin{array}{l}\text { West Indians } \\
\text { Other Immigrants } \\
\text { UK-born }\end{array}$ & $\cdots$ & $\begin{array}{l}\cdots \\
\cdots\end{array}$ & $\begin{array}{c}\text { Increase of } 59 \cdot 1 \text { per cent. } \\
\left.\begin{array}{c}54 \cdot 5 \\
20 \cdot 8 \\
24 \cdot 7\end{array}\right\} 75 \cdot 3\end{array}$ & $\begin{array}{c}\text { Increase of } 31 \cdot 8 \text { per cent. } \\
\left.\begin{array}{c}37 \cdot 7 \\
28 \cdot 6 \\
33 \cdot 7\end{array}\right\} 66 \cdot 3\end{array}$ & $\begin{array}{c}\text { Decrease of } 1 \cdot 6 \text { per cent. } \\
\text { na } \\
\text { na } \\
\text { na }\end{array}$ \\
\hline & Total & $\ldots$ & $\ldots$ & $100 \cdot 0$ & $100 \cdot 0$ & na \\
\hline \multirow[t]{2}{*}{ Female } & $\begin{array}{l}\text { West Indians } \\
\text { Other Immigrants } \\
\text { UK-born } \ldots\end{array}$ & $\cdots$ & $\begin{array}{l}\ldots \\
\cdots \\
\cdots\end{array}$ & $\begin{array}{c}\text { Increase of } 45 \cdot 7 \text { per cent. } \\
\left.\begin{array}{c}16 \cdot 4 \\
3 \cdot 2 \\
80.4\end{array}\right\} 19 \cdot 6\end{array}$ & $\begin{array}{c}\text { Increase of } 38 \cdot 2 \text { per cent. } \\
\left.\begin{array}{c}20 \cdot 0 \\
15 \cdot 5 \\
64 \cdot 5\end{array}\right\} 35 \cdot 5\end{array}$ & $\begin{array}{c}\text { Increase of } 13 \cdot 5 \text { per cent. } \\
-0 \cdot 3\} 12 \cdot 9 \\
\begin{array}{c}13 \cdot 2 \\
87 \cdot 1\end{array}\end{array}$ \\
\hline & Total & . & . & $100 \cdot 0$ & $100 \cdot 0$ & $100 \cdot 0$ \\
\hline
\end{tabular}


cent. by West Indians) and only $24 \cdot 7$ per cent. by men born in the United Kingdom.

1958-61.- Infections rose from 22,398 to 29,519 , although the percentage increase fell to 31.8 per cent. Immigrants accounted for $66 \cdot 3$ per cent. of this increase (West Indians for $37 \cdot 7$ per cent.) - both slightly lower than in the earlier period.

1961-4.--Infections decreased very slightly by approximately 470 cases (1.6 per cent.); this was accounted for almost entirely by a fall of over 1,500 in the number of West Indians, whereas that of other immigrants increased by over 300 and that of those born in the United Kingdom by over 700 .

Females (Fig. 6B)

1955-8.-Gonococcal infections rose from 3,766 to 5,480 (an increase of $45 \cdot 7$ per cent.). Only 19.6 per cent. was accounted for by immigrants $(16.4$ per cent. by West Indians), 80.4 per cent. being contributed by females born in the United Kingdom.

1958-61.-Infections rose further from 5,489 to $7,588(38 \cdot 2$ per cent.). The share of immigrants had increased to 35.5 per cent. (20 per cent. West Indians) and that of United Kingdom-born females had fallen to a little under two-thirds.

1961-4.-Unlike the males, who showed a slight decrease, there was a continued-if small-increase in female cases from 7,588 to $8,615(13 \cdot 5$ per cent.). This increase was not due to West Indian females, who showed an almost identical number in the 2 years, but $87 \cdot 1$ per cent. of it was accounted for by United Kingdom-born women and the remainder by other immigrants.

Thus, since 1961 infections contracted by persons born in the United Kingdom have formed an increasing proportion of the cases of gonorrhoea.

\section{Importation of Venereal Disease}

Ministry of Health figures for 1963 have indicated that the importation of infection from abroad is of much greater significance for syphilis than for gonorrhoea and for males than for females. The percentage of imported cases of gonorrhoea (when information was available) was 6.6 per cent. for males and only 0.8 per cent. for females, while that for primary and secondary syphilis was as high as 25.6 per cent. for males but only 4.9 per cent. for females.

Syphilis is well known to be frequently imported and exported, particularly by sailors. Hartmann (1955), in a study of syphilis in Copenhagen (where there is no great immigrant problem), found that 47 per cent. of known infections could be traced directly or indirectly to sailors, and that 35 per cent. of those likely to be infected left the city and went abroad again.

The country of origin of patients importing gonorrhoea into Great Britain is not known, but a recent study by the British Cooperative Clinical
Group (1965) of the importation of primary and secondary syphilis into Great Britain, showed that importation was an insignificant problem in females, whereas 290 ( 28.5 per cent.) of 1,016 male cases for which information was available were imported. Of this total number of 1,016 cases, 163 (16 per cent.) were imported by immigrants, 239 cases $(23.5$ per cent.) were contracted by immigrants in the United Kingdom, 127 cases ( 12.5 per cent.) were imported by United Kingdom-born persons, and the remaining 487 ( 47.9 per cent.) were contracted by United Kingdom-born persons at home (Table VI and Fig. 7).

TABLE VI

PRIMARY AND SECONDARY SYPHILIS: IMPORTED AND HOME-CONTRACTED INFECTIONS (England and Wales)

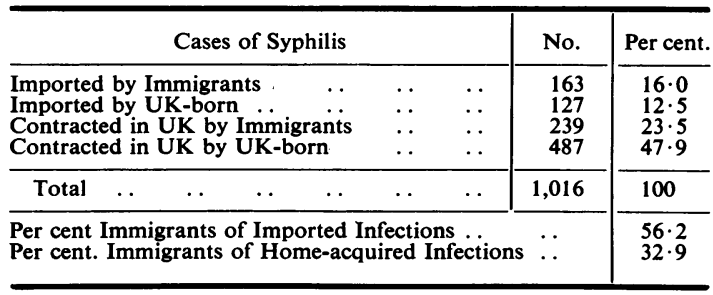

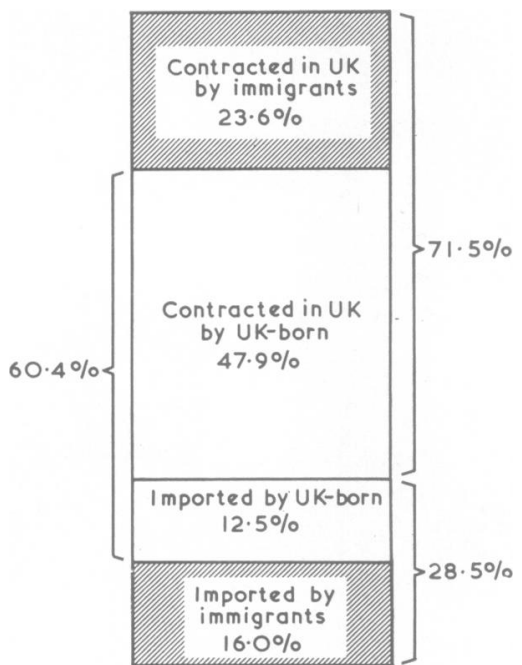

FIG. 7.-Imported and UK-contracted primary and secondary syphilis, England and Wales.

Immigrants were thus responsible not only for 56.2 per cent. of imported infections, but also for 32.9 per cent. of those contracted in the United Kingdom.

The proportions of imported infections in West Indians, other immigrants, and United Kingdomborn persons with primary and secondary syphilis are shown in Table VII and Fig. 8 (opposite). 
TABLE VII

PERCENTAGE OF IMPORTED INFECTIONS IN DIFFERENT RACIAL GROUPS

\begin{tabular}{|c|c|c|c|c|c|c|}
\hline \multirow{2}{*}{\multicolumn{4}{|c|}{ Race }} & \multirow{3}{*}{$\begin{array}{r}\text { Total } \\
\text { Cases } \\
55 \\
614 \\
347\end{array}$} & \multicolumn{2}{|c|}{ Imported } \\
\hline & & & & & No. & $\begin{array}{l}\text { Per } \\
\text { cent. }\end{array}$ \\
\hline $\begin{array}{l}\text { West Indians } \\
\text { UK-born } \\
\text { Other Immigrants }\end{array}$ & $\begin{array}{l}\cdots \\
\cdots \\
\cdots\end{array}$ & $\begin{array}{l}\cdots \\
\cdots \\
\cdots\end{array}$ & $\begin{array}{l}\cdots \\
\cdots \\
\cdots\end{array}$ & & $\begin{array}{r}7 \\
127 \\
156\end{array}$ & $\begin{array}{l}12 \cdot 7 \\
20 \cdot 7 \\
45 \cdot 0\end{array}$ \\
\hline Total & $\ldots$ & . & . & 1,016 & 290 & $28 \cdot 5$ \\
\hline
\end{tabular}

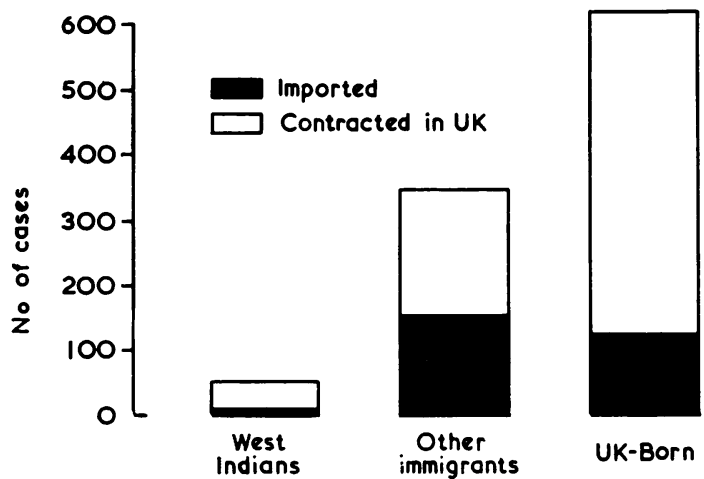

FIG. 8.-Relative numbers of imported infections with primary and secondary syphilis, by racial groups.

Of the three groups, the West Indians had substantially the lowest proportion of imported infections and other immigrants the highest.

Of the imported cases, 43.8 per cent. affected UK-born persons, 53.8 per cent. other immigrants, and only 2.4 per cent. West Indians. The West Indians comprised a lower proportion of imported infections than of infections contracted in the United Kingdom (6.6 per cent.)-see Table VIII and Fig. 9.

TABLE VIII

RACIAL GROUPS IN IMPORTED CASES OF PRIMARY AND SECONDARY SYPHILIS CONTRASTED WITH THOSE OF U.K.-CONTRACTED INFECTIONS

\begin{tabular}{|c|c|c|c|c|c|}
\hline \multirow{2}{*}{ Race } & & \multicolumn{2}{|c|}{ Imported } & \multicolumn{2}{|c|}{ UK-acquired } \\
\hline & & No. & Per cent. & No. & Per cent. \\
\hline $\begin{array}{l}\text { West Indians } \\
\text { Other Immigrants } \\
\text { UK-born .. }\end{array}$ & $\begin{array}{l}\ldots \\
\cdots\end{array}$ & $\begin{array}{r}7 \\
156 \\
127\end{array}$ & $\begin{array}{r}2 \cdot 4 \\
53 \cdot 8 \\
43 \cdot 8\end{array}$ & $\begin{array}{r}48 \\
191 \\
487\end{array}$ & $\begin{array}{r}6 \cdot 6 \\
26 \cdot 3 \\
67 \cdot 1\end{array}$ \\
\hline Totals & $\ldots$ & 290 & $100 \cdot 0$ & 726 & $100 \cdot 0$ \\
\hline
\end{tabular}

The breakdown for individual immigrant groups is shown in Table IX and Fig. 10.

Of the immigrants importing infections, Europeans and Asians were by far the most important groups, with all Negro groups the least prominent. Asians, West Indians, and those born in Eire comprised the

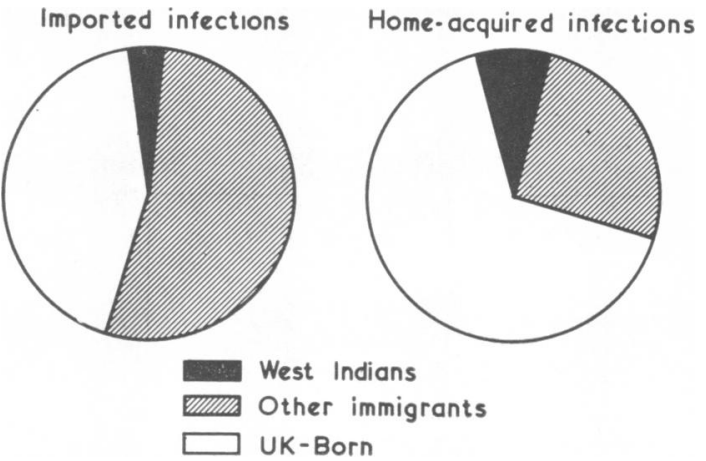

FIG. 9.-Racial groups of imported and UK-acquired infections with primary and secondary syphilis.

TABLE IX

IMPORTATION OF PRIMARY AND SECONDARY SYPHILIS BY INDIVIDUAL IMMIGRANT GROUPS

\begin{tabular}{|c|c|c|c|c|c|}
\hline \multirow{2}{*}{\multicolumn{2}{|c|}{ Immigrant Groups }} & \multicolumn{2}{|c|}{ Imported } & \multicolumn{2}{|c|}{ Home-acquired } \\
\hline & & No. & Per cent. & No. & Per cent. \\
\hline $\begin{array}{l}\text { Europeans } \\
\text { Asiatics } \ldots \\
\text { Mediterranean-born } \\
\text { Other Non-negro } \\
\text { Eire } \\
\text { African Negro } \\
\text { West Indies Negro } \\
\text { Other Negro }\end{array}$ & $\begin{array}{l}\cdots \\
\cdots \\
\cdots \\
\cdots \\
\cdots\end{array}$ & $\begin{array}{r}68 \\
39 \\
15 \\
13 \\
11 \\
8 \\
7 \\
2\end{array}$ & $\begin{aligned} 41 \cdot 7 \\
23 \cdot 9 \\
9 \cdot 2 \\
8 \cdot 0 \\
6 \cdot 7 \\
4 \cdot 9 \\
4 \cdot 3 \\
1 \cdot 2\end{aligned}$ & $\begin{array}{r}27 \\
67 \\
26 \\
13 \\
45 \\
10 \\
48 \\
3\end{array}$ & $\begin{array}{r}11 \cdot 3 \\
28 \cdot 0 \\
10 \cdot 9 \\
5 \cdot 4 \\
18 \cdot 8 \\
4 \cdot 2 \\
20 \cdot 1 \\
1 \cdot 3\end{array}$ \\
\hline Total & $\cdots$ & 163 & $100 \cdot 0$ & 239 & $100 \cdot 0$ \\
\hline
\end{tabular}

\begin{tabular}{|c|c|c|}
\hline Percentoge UK-ocquired & Percentoge impor & \\
\hline $11 \cdot 3$ & $41 \cdot 7$. & Europeans \\
\hline $28 \cdot 0$ & $23 \cdot 9$ & Asions \\
\hline 10.9 & $9 \cdot 2$ & Mediterronean \\
\hline 5.4 & 8.0 & Other non-negro \\
\hline $18 \cdot 8$ & 6.7 & Eire \\
\hline $4 \cdot 2$ & 4.9 & Africons \\
\hline $20 \cdot 1$ & $4 \cdot 3$ & West Indians \\
\hline $1 \cdot 3$ & 1.2 & Other negro \\
\hline
\end{tabular}

FIG. 10.-Percentage imported and UK-acquired infections with primary and secondary syphilis by different racial groups.

most significant groups of infections acquired in the United Kingdom.

It may also be noted that the majority of infections in Europeans were imported, and that in other non-Negroes the numbers of infections imported and contracted in the United Kingdom were about equal. In Asians, those born in the Mediterranean region or in Eire, and in all three Negro groups, the majority of infections were acquired in the United Kingdom.

Although "immigrants" were responsible for $56 \cdot 2$ per cent. of imported infections, many of these 
patients are likely to have been no true immigrants but seamen. Of the 163 infections imported by immigrants, no less than 112 (68.7 per cent.) were encountered in the 31 port clinics of the 167 clinics participating. In these port clinics the proportion of mariners amongst venereal disease patients may exceed 50 per cent. (Schofield, 1965).

\section{Female Consorts of Immigrants with Venereal Disease}

In general "like" tends to consort with "like". In a British Cooperative Clinic Group (1965a) study of 4,093 female contacts of male cases of gonorrhoea seen in the clinics of England and Wales, 49.1 per cent. of the female contacts of West Indian males were themselves West Indians while 44.7 per cent. were born in the United Kingdom. Likewise 40.5 per cent. of the female contacts of other immigrant

TABLE X

RACIAL GROUPS OF FEMALE CONTACTS OF IMMIGRANT AND OTHER MALES WITH GONORRHOEA (PER CENT.)

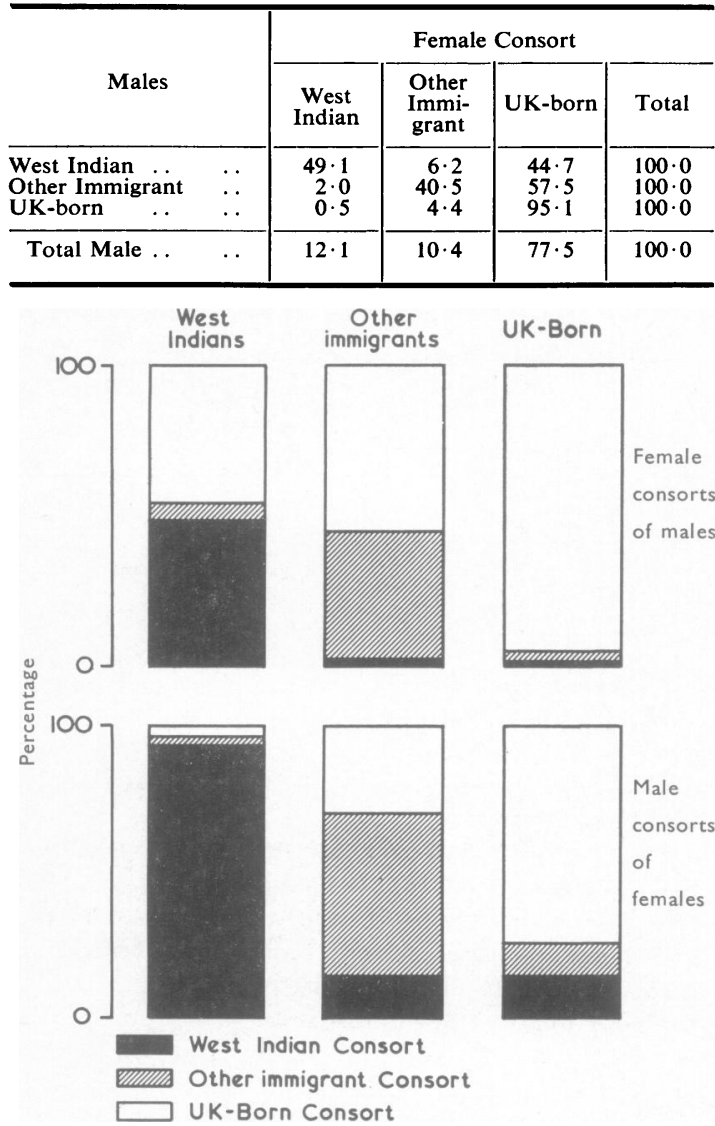

FIG. 11.-Race of partners of immigrant and UK-born cases of gonorrhoea shown as percentage of total. males were other immigrants while 57.5 per cent. were UK-born; $95 \cdot 1$ per cent. of the female contacts of UK-born males were also UK-born (Table X and Fig. 11). Indeed, of the 1,595 male immigrants involved in the study, in 795 (49.8 per cent.) the consort was born in the United Kingdom and in 50.2 per cent. the consort was also an immigrant.

Among females the tendency for "like" to consort with "like" is even more marked. The male consorts of 94.7 per cent. of female West Indians were also West Indian, those of 60.7 per cent. of other immigrant females was also other immigrants, and those of 74.9 per cent. of UK-born females were UK-born males (Table XI).

TABLE XI

RACIAL GROUPS OF REFERRING MALES OF IMMIGRANT AND OTHER FEMALE GONORRHOEA CONTACTS (per cent.)

\begin{tabular}{|c|c|c|c|c|c|}
\hline \multirow[b]{2}{*}{ Females } & & \multicolumn{4}{|c|}{ Referring Male } \\
\hline & & $\begin{array}{c}\text { West } \\
\text { Indian }\end{array}$ & $\begin{array}{l}\text { Other } \\
\text { Immi- } \\
\text { grant }\end{array}$ & UK-born & Total \\
\hline $\begin{array}{l}\text { West Indian ... } \\
\text { Other Immigrant } \\
\text { UK-born }\end{array}$ & $\begin{array}{l}\ldots \\
\cdots\end{array}$ & $\begin{array}{l}94 \cdot 7 \\
13 \cdot 8 \\
13 \cdot 5\end{array}$ & $\begin{array}{r}2 \cdot 6 \\
60 \cdot 7 \\
11 \cdot 6\end{array}$ & $\begin{array}{r}2 \cdot 6 \\
25 \cdot 5 \\
74.9\end{array}$ & $\begin{array}{l}100 \cdot 0 \\
100 \cdot 0 \\
100 \cdot 0\end{array}$ \\
\hline Total Female & $\ldots$ & $23 \cdot 3$ & $15 \cdot 6$ & $61 \cdot 0$ & $100 \cdot 0$ \\
\hline
\end{tabular}

Of 922 female immigrant contacts, only $122(13 \cdot 2$ per cent.) were referred by UK-born males and the rest ( 86.8 per cent.) by immigrant males.

These data, however, take no account of which consorts were primary source contacts and which were secondary contacts made after the infection was acquired.

As a result of recent intensified contact-tracing of West Indian males with gonorrhoea at St. Mary's Hospital more precise information has been made available (Table XII and Fig. 12, opposite). The bulk of the sources of infection of West Indian males in the West End of London (57.9 per cent.) were women born in the United Kingdom, while the great majority ( 79.8 per cent.) of the secondary contacts were West Indian females.

\section{Relationship of Immigrants with Venereal Infection in Teenagers}

Another epidemiological phenomenon of recent times is the increase in venereal infections amongst teenagers.

By 1963 in England and Wales, $25 \cdot 3$ per cent. of gonococcal infections in females and $7 \cdot 8$ per cent. in males occurred in persons of 15 to 19 years of age. This age group also accounted for 24 per cent. of cases of primary and secondary syphilis in females and 6.6 per cent. in males (Ministry of Health, 1964). 
TABLE XII

RACE OF ATTENDING FEMALE WEST INDIAN CONTACTS (St. Mary's. 1964-1965)

\begin{tabular}{|c|c|c|c|c|c|}
\hline \multirow{2}{*}{ Race } & & \multicolumn{2}{|c|}{$\begin{array}{l}\text { Suspected } \\
\text { Sources }\end{array}$} & \multicolumn{2}{|c|}{$\begin{array}{l}\text { Secondary } \\
\text { Contacts }\end{array}$} \\
\hline & & No. & Per cent. & No. & Per cent. \\
\hline $\begin{array}{l}\text { West Indian . } \\
\text { Other Immigrant } \\
\text { UK-born }\end{array}$ & $\begin{array}{l}\cdots \\
\cdots \\
\cdots\end{array}$ & $\begin{array}{l}26 \\
19 \\
62\end{array}$ & $\begin{array}{l}24 \cdot 3 \\
17 \cdot 8 \\
57 \cdot 9\end{array}$ & $\begin{array}{r}71 \\
7 \\
11\end{array}$ & $\begin{array}{r}79 \cdot 8 \\
7 \cdot 9 \\
12 \cdot 3\end{array}$ \\
\hline Total & 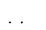 & 107 & $100 \cdot 0$ & 89 & $100 \cdot 0$ \\
\hline
\end{tabular}
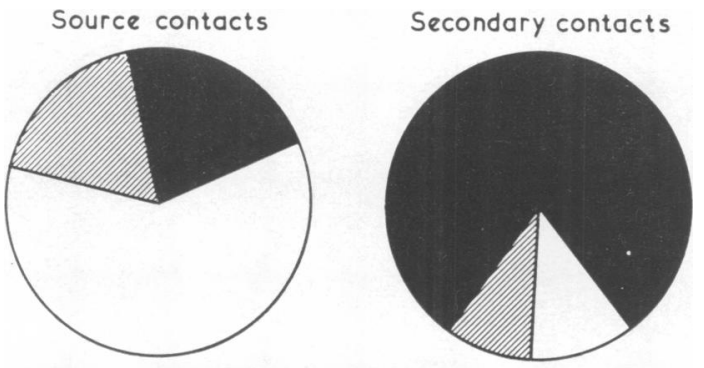

West Indians

Other immigrants

UK-Born

FIg. 12. - Race of female West Indian contacts (St. Mary's)

The teenage problem has been shown to be on the increase in many parts of the world. For example, in the U.S.A. in 1956, there were 1,093 cases of infectious syphilis and 44,264 cases of gonorrhoea in those aged 15 to 19 years; these figures had risen to 3,438 and 54,509 respectively by 1963 (Joint Statement, 1965). In Sweden nearly one-third of new female cases of gonorrhoea occur in girls aged 15 to 19 years and the greatest increase in both gonorrhoea and syphilis has been in this group (Medical New's, 1965). Rising gonorrhoea rates in teenagers have also been reported from Denmark (Lind, 1962) and elsewhere. However, in both Denmark and Sweden, there is no great "immigrant" population. Is there any evidence to connect the problem of venereal disease in young people in Great Britain with immigrants?

Some information regarding West Indians is available from the British Cooperative Clinic Group Studies for the years 1960 to $1962 ; 87.5$ to 89.8 per cent. of male West Indians were treated at between 20 and 32 clinics, and only 10.2 to 12.5 per cent. in the remaining 120 to 134 clinics. In all three years the percentage of female teenagers seen at the clinics where most West Indians were treated was lower $(23.2$ to 24.9 per cent.) than that in the clinics with very few West Indian patients $(27 \cdot 7$ to 28.9 per cent.) - see Table XIII and Fig. 13.
TABLE XIII

PERCENTAGE OF FEMALE TEENAGERS TREATED IN CLINICS WITH MANY AND FEW WEST INDIANS WITH GONORRHOEA

\begin{tabular}{lcc|c|c|c}
\hline \multicolumn{1}{l}{ Year } & $\ldots$ & $\ldots$ & 1960 & 1961 & 1962 \\
\hline Per cent. West Indians & $\ldots$ & $\ldots$ & $88 \cdot 8$ & $89 \cdot 8$ & $87 \cdot 5$ \\
No. of Clinics & $\ldots$ & $\ldots$ & 20 & 30 & 32 \\
Per cent. Girls aged is to 19 & $\ldots$ & $24 \cdot 9$ & $24 \cdot 0$ & $23 \cdot 2$ \\
\hline Per cent. West Indians & $\ldots$ & $\ldots$ & $11 \cdot 2$ & $10 \cdot 2$ & $12 \cdot 5$ \\
No. of other Clinics & $\ldots$ & $\ldots$ & 130 & 120 & 134 \\
Per cent. Girls aged i5 to 19 & $\ldots$ & $28 \cdot 9$ & $28 \cdot 8$ & $27 \cdot 7$ \\
\hline
\end{tabular}

Females aged $15-19$ yrs

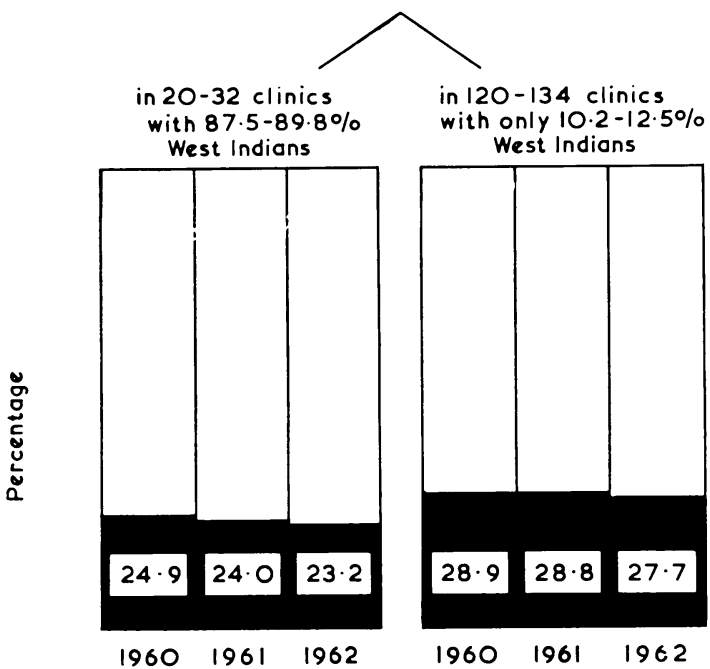

Fici. 13.--Percentage of young females treated at clinics with many or few West Indian male patients with gonorrhoea.

In the study of 4,093 female contacts of males with gonorrhoea (B.C.C.G., 1965a), the findings were to some extent limited by our not knowing how many were the primary source of male infection and how many were secondary contacts (e.g. wives, fiancées, etc.) which might include more older women than the primary sources. However, within these limits, the female contacts of immigrants-particularly West Indians-included a lower proportion of teenagers than those of male patients born in the United Kingdom (Table XIV, and Fig. 14, overleaf).

TABLE XIV

PERCENTAGE AGE GROUPS OF FEMALE CONTACTS OF MALE PATIENTS WITH GONORRHOEA IN V.D. CLINICS IN ENGLAND AND WALES

\begin{tabular}{cc|c|c|c}
\hline \multicolumn{2}{c|}{\begin{tabular}{c}
\multicolumn{3}{c}{ Referring Male } \\
(yrs)
\end{tabular}} & \multicolumn{2}{|c}{$\begin{array}{c}\text { West Indian } \\
\text { (yroup }\end{array}$} & $\begin{array}{c}\text { Other Immigrant } \\
\text { UK-born }\end{array}$ \\
\hline $15-19 \ldots$ & $\cdots$ & $16 \cdot 3$ & $23 \cdot 4$ & $25 \cdot 3$ \\
$20-24 \ldots$ & $\cdots$ & $40 \cdot 7$ & $38 \cdot 0$ & $34 \cdot 3$ \\
Others & $\cdots$ & $42 \cdot 9$ & $38 \cdot 6$ & $40 \cdot 4$ \\
\hline Total & $\cdots$ & $100 \cdot 0$ & $100 \cdot 0$ & $100 \cdot 0$ \\
\hline
\end{tabular}




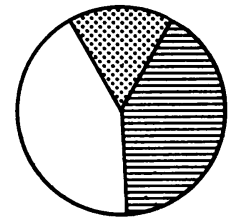

West Indians

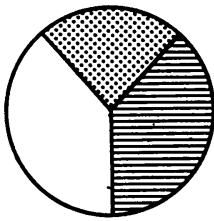

Other immigrants

$15-19$ yrs

20-24yrs

$\square$ others

FIG. 14.-Ages of female contacts of male cases of gonorrhoea, by racial origin of males.

If the number of men attending the clinics is compared with that of the teenage female contacts, the ratio is only 2.6 and 2.3 per cent. for West Indian and other immigrant males respectively but is 5.7 to one for UK-born males (Fig. 15).

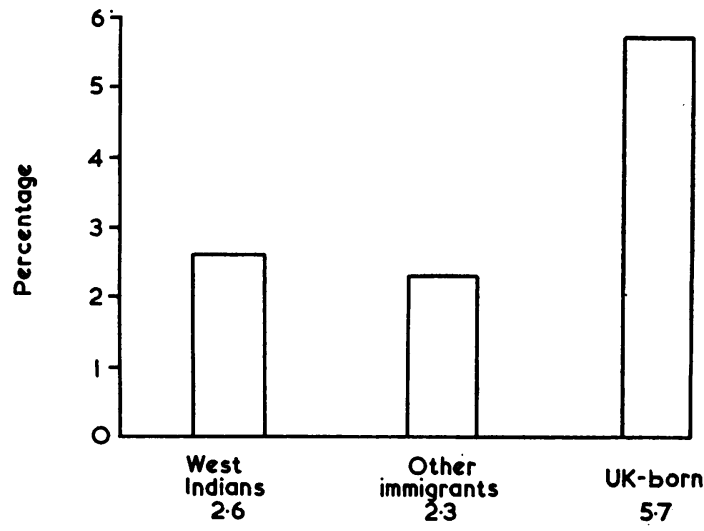

FIG. 15.-Female patients aged 15-19 years expressed as a percentage of male cases.

These figures may merely reflect the greater difficulty in tracing the contacts of immigrants, but they do not suggest that immigrants are directly connected with the problem of gonorrhoea in teenage girls, although the two problems must obviously overlap in some areas.

For example, data from St. Mary's of the female contacts of West Indian males with gonorrhoea interviewed by the social worker show that the source contacts are generally much younger than the secondary contacts (Table XV; Fig. 16).

Of the source contacts attending the clinic, approximately three-quarters were under the age of 25 years, and $41 \cdot 1$ per cent. were under the age of 20 . On the other hand, only $10 \cdot 2$ per cent. of the secondary contacts were under 20 and virtually onehalf were 25 years and over. Of the 44 suspected sources aged 15 to 19 years, 25 ( 56.8 per cent.) were born in the United Kingdom, twelve (27.3 per

TABLE XV

AGE OF FEMALE CONTACTS OF MALE WEST INDIANS (St. Mary's, 1964-5)

\begin{tabular}{c|c|c|c|c}
\hline $\begin{array}{c}\text { Age } \\
\text { Group } \\
\text { (yrs) }\end{array}$ & \multicolumn{2}{|c|}{ Suspected Sources } & \multicolumn{2}{c}{ Secondary Contacts } \\
\cline { 2 - 4 } & No. & Per cent. & No. & Per cent. \\
\hline $15-19 \quad \ldots$ & 44 & $41 \cdot 1$ & 9 & $10 \cdot 2$ \\
$20-24 \ldots$ & 36 & $33 \cdot 6$ & 36 & $40 \cdot 4$ \\
25 and over & 27 & $25 \cdot 2$ & 44 & $40 \cdot 4$ \\
\hline Totals.. & 107 & $100 \cdot 0$ & 89 & $100 \cdot 0$ \\
\hline
\end{tabular}

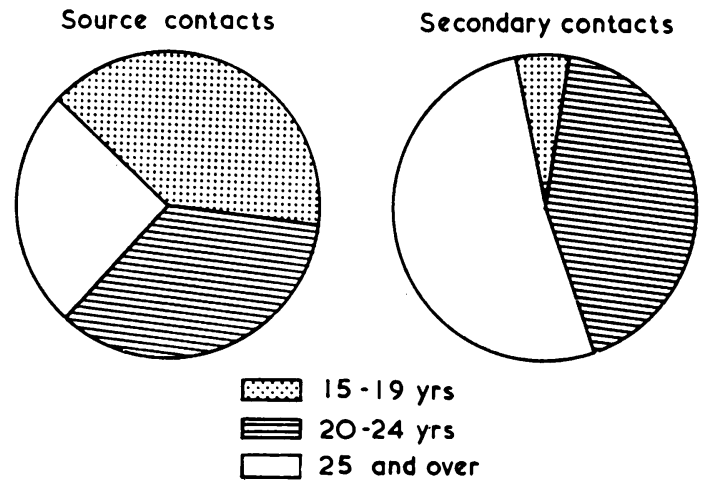

Fig. 16.-Female source and secondary contacts of West Indian male gonorrhoea patients (St. Mary's), by age group.

cent.) were West Indians, and seven (15.9 per cent.) were other immigrants.

Such data indicate some of the future scope for profitable epidemiological studies on a co-operative basis through the now expanding number of contact interviewers in the clinics.

Success of Contact-Tracing in Immigrants

Contact-tracing as a result of interviewing male West Indians with gonorrhoea at St. Mary's (Table XVI) has demonstrated the usual pattern of finding more secondary contacts than primary source contacts (Dunlop, 1963).

TABLE XVI

SUCCESS OF CONTACT-TRACING AMONGST MALE WEST INDIANS WITH GONORRHOEA

\begin{tabular}{|c|c|c|c|c|c|}
\hline \multirow{2}{*}{ Contacts } & \multirow[b]{2}{*}{$\cdots$} & \multirow{2}{*}{. } & \multirow{2}{*}{ Source } & \multicolumn{2}{|c|}{ Secondary } \\
\hline & & & & Promiscuous & $\begin{array}{c}\text { Non- } \\
\text { promiscuous }\end{array}$ \\
\hline \multicolumn{3}{|c|}{ Total Known Contacts } & 531 & 106 & 9 \\
\hline \multirow{2}{*}{ Attended } & $\begin{array}{l}\text { Same } \\
\text { Clinic }\end{array}$ & $\begin{array}{l}\text { No. } \\
\text { Per cent. }\end{array}$ & $\begin{array}{r}107 \\
20 \cdot 2\end{array}$ & $\begin{array}{r}89 \\
84 \cdot 0\end{array}$ & $22 \cdot 2$ \\
\hline & $\begin{array}{l}\text { Same or } \\
\text { Other } \\
\text { Clinics }\end{array}$ & $\begin{array}{l}\text { No. } \\
\text { Per cent. }\end{array}$ & $\begin{array}{r}129 \\
24 \cdot 3\end{array}$ & $\begin{array}{r}97 \\
91 \cdot 5\end{array}$ & $22 \cdot 2$ \\
\hline \multicolumn{2}{|c|}{$\begin{array}{l}\text { Sources found in All } \\
\text { Clinics allowing for } \\
\text { Multiple Infections }\end{array}$} & $\begin{array}{l}\text { No. } \\
\text { Per cent. }\end{array}$ & $\begin{array}{r}157 \\
29 \cdot 6\end{array}$ & - & - \\
\hline
\end{tabular}


Of 531 male West Indian patients with gonorrhoea who were interviewed, 107 individual female sources attended the same clinic $(20.2$ per cent.); if those known to have attended other clinics and girls known to have caused multiple infections in the group are allowed for, the percentage of sources traced could be raised to 29.6 per cent.

With non-promiscuous secondary contacts, on the other hand, the picture was quite different. Of 106 such persons, 89 ( 84 per cent.) attended the same clinic, and if those known to have attended other clinics are included the total traced was 91.5 per cent. Among a small number of promiscuous secondary contacts, on the other hand, the results were no better than with the promiscuous primary sources of infection.

Thus, by and large, the overall results were much the same as those reported at the last meeting of all nationalities using similar methods at the Whitechapel clinic.

\section{Homosexuals amongst Immigrant V.D. Patients}

Venereal disease amongst homosexuals has become an increasing problem in the larger cities, especially with regard to syphilis. There are at least four clinics in London in which more than 50 per cent. of patients with early syphilis are homosexuals. Figures of up to 15 per cent. of gonococcal infections in males are also encountered.

However, at St. Mary's, this is more a problem of the home population than of immigrants, and it is apparently of less importance among West Indians, although it is not unlikely that UK-born persons

TABLE XVII

PROPORTION OF ADMITTED HOMOSEXUALS AMONGST MALE V.D. PATIENTS

(St. Mary's, May to June, 1965)

\begin{tabular}{|c|c|c|c|c|}
\hline \multirow{2}{*}{\multicolumn{2}{|c|}{ Race }} & \multirow{2}{*}{$\begin{array}{c}\text { Total Cases } \\
\text { (all conditions) }\end{array}$} & \multicolumn{2}{|c|}{ Homosexuals } \\
\hline & & & No. & Per cent. \\
\hline $\begin{array}{l}\text { West Indian } \\
\text { Other Immigrant } \\
\text { UK-born } \ldots\end{array}$ & $\begin{array}{ll}\cdots & \cdots \\
\cdots & \cdots \\
\cdots & \cdots\end{array}$ & $\begin{array}{l}278 \\
452 \\
566\end{array}$ & $\begin{array}{r}5 \\
37 \\
158\end{array}$ & $\begin{array}{r}1 \cdot 8 \\
8 \cdot 2 \\
27 \cdot 9\end{array}$ \\
\hline Total & $\ldots$ & 1,296 & 200 & $15 \cdot 5$ \\
\hline
\end{tabular}

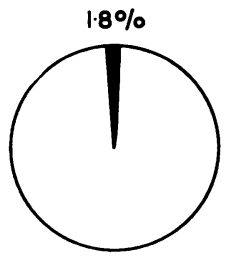

West Indians
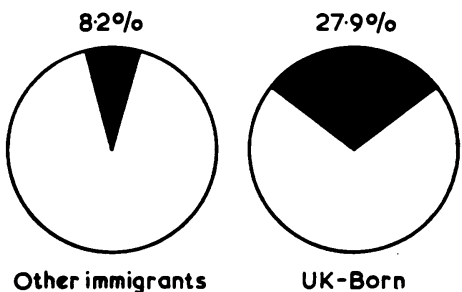

UK-Born
FIG 17.--Percentage admitted homosexuals amongst male VD patients (St. Mary's), by racial origin. may be less reluctant to admit such practices than certain immigrants (Table XVII and Fig. 17). The higher rates of heterosexual infections among immigrant groups could dilute the numbers of homosexuals which might in fact be numerically proportionately similar. Homosexuals are in fact encountered in all groups.

\section{Social Considerations}

The reasons why immigrants are prone to contact venereal disease are manifold. Some, but by no means all, come from areas where promiscuity is commonplace-the origins of their sexual habits being entrenched in the past-and such persons merely continue their accustomed way of life. Immigrants are usually males in search of work, or are engaged on itinerant duties forced on them for one reason or another. They are often young, sexually-active and curious, but find themselves removed from the parental, familial, tribal, marital, religious, and other influences which may inhibit promiscuity.

In a foreign country, differences in race, creed, colour, culture, religion, and language-at least during the years required for adjustment, and while it is difficult to find other than doss-house accommodation-make it hard to establish a firm relationship with a member of the opposite sex. There are not enough suitable females for equitable distribution, and the men probably have more money to spend than has been their custom.

The sexual demand thus created is satisfied partly by the few available female immigrants and partly by promiscuous women of the local population; the latter are often prostitutes eager to capitalize on the available money or near-prostitutes and other women of low type, all with high rates of venereal infection.

If the prevention of venereal disease were the only consideration, the remedy would lie either in bringing in suitable numbers of female immigrants or in the acceptance of immigrants into all aspects of community life (including unrestricted intermarriage and equal facilities for housing accommodation).

However, even if this could be successfully achieved, the venereal disease situation amongst immigrants would then be about the same as that in the home population. And this, despite modern rapid and effective treatment, has in itself been an increasing problem!

\section{Summary and Conclusions}

(1) Male immigrants are currently responsible for about one-half of the cases of gonorrhoea attending the clinics of England and Wales 
and for about four out of ten cases of primary and secondary syphilis. In females approximately four out of five cases of both conditions occur in those born in the United Kingdom. These figures have also to be considered in relation to the total number of immigrants and of the home population.

(2) With gonorrhoea, the West Indians, who are calculated to have infection rates in both sexes more than nineteen times higher than the home population, are the most prominent group with Asians the second. The patients in immigrant groups (except Europeans) showed a significant rise during the years 1952 to 1961 , but have since decreased (except Asians and Europeans). In both sexes, however, the number of cases in persons born in the United Kingdom continues to rise.

(3) Much of the increase in gonorrhoea in males is accounted for by immigrants. There has, however, been a consistent overall increase in men born in the United Kingdom, and, even without immigrants, there would still be an increasing venereal disease problem.

(4) A little over one-quarter of male infections with primary and secondary syphilis are imported, while for gonorrhoea the proportion is only one in fifteen; among females importation of both diseases is relatively insignificant. Immigrants in the widest sense are responsible for a little over one-half of imported cases, but it is likely that a large proportion of these are in fact seamen. Immigrants are also responsible for about one-third of cases of primary and secondary syphilis acquired in the United Kingdom and, excluding Europeans and other non-Negro groups, the majority of their early syphilitic infections are contracted in this country.

(5) Of known female contacts of male immigrants with gonorrhoea about one-half are also immigrants and about one-half are local women. A noticeable tendency for "like" to consort with "like" is noted. However, if only source contacts of West Indians are considered, nearly six out of ten may be UK-born females.

(6) The data suggest that the high incidence of venereal disease in teenage girls is apparently not directly related to high rates amongst immigrants, although the two problems obviously overlap in some areas. At St. Mary's no less than 41 per cent. of source contacts of West Indian males are teenagers.
(7) Contact-tracing through patient interviewing in London is apparently as successful among West Indians as among other groups.

(8) Homosexuality has emerged as a significant factor in the epidemiology of venereal diseases, especially of syphilis. Data from one London clinic would indicate that the proportion of admitted homosexuals was nearly five times higher in United Kingdom-born patients than in immigrants, but this may not be a true figure.

(9) Social reasons for high venereal disease rates amongst immigrants are outlined. The spread of venereal disease may be prevented by bringing in female immigrants to match the males or by the complete acceptance by society of immigrant groups - with all that this implies-or by a judicious admixture of both measures. However, even if these measures were successfully applied, venereal disease rates amongst immigrants could scarcely fall below those of the home population, and these are themselves a matter of mounting concern!

\section{REFERENCES}

British Cooperative Clinical Group (1965). Brit. J. vener. Dis., 32, 21.

(1960). Ibid., 36, 233.

(1962). Ibid., 38, 1.

(1963a). Ibid., 39, 1.

(1963b). Ibid., 39, 149.

(1964). Ibid., 40, 242.

(1965a). Ibid., 41, 24.

(1965b). Ibid., 41, 30

Dunlop, E. M. C. (1963). Ibid., 39, 109.

Guthe, T., and Willcox, R. R. (1954). Chron. Wld Hlth Org., 8, 37.

Hartmann, G. (1955). WHO Working Document WHO/VDT/137.

Joint Statement of the Association of State and Territorial Health Officers, the American Venereal Diseases Association, and the American Social Health Association (1965). "Today's V.D. Control Problem".

Lancereaux, E. (1868). "A Treatise on Syphilis". New Sydenham Society, London.

Lind, I. (1962). WHO Working Document WHO/VDT/ 296.

Medical News (London) (1965). June 25, p. 15.

Ministry of Health (1965). "Annual Report of the Chief Medical Officer for 1964" (Brit.J. vener. Dis., 1966, 42, 50).

Rasmussen, S. E. (1947). "London; the Unique City". Cape, London.

Schofield, C. B. S. (1965). Brit. J. vener. Dis., 41, 51.

Willcox, R. R. (1958). Int. Rev. Criminal Policy (United Nations), No. 13, p. 67. (1963). Brit. J. vener. Dis., 39, 214.

(1965). Brit. J. clin. Pract., 19, 255. 
WHO (1964). "European Symposium on Venereal Disease Control-Stockholm, 24-28 September, 1963". WHO Regional Office for Europe, Copenhagen.

\section{L'immigration et les maladies vénériennes en Grande Bretagne \\ RÉSUMÉ ET CONCLUSIONS}

(1) Les immigrants mâles sont couramment responsables d'à peu près la moitié des cas de blennorragie qui visitent les dispensaires de l'Angleterre et du pays de Galles et d'à peu près quatre des dix cas de syphilis primaire et secondaire. Chez les femmes à peu près quatre sur cinq des cas de ces deux stages se trouvent chez celles nées au Royaume-Uni. Ces chiffres doivent aussi être considérés en relation du nombre total d'immigrants et de celui de la population métropolitaine.

(2) Dans le case de la blennorragie les Antillais ont un taux d'infection pour les deux sexes dix-neuf fois plus élevé que celui de la population métropolitaine et forment le groupe le plus important suivi du groupe asiatique. Les malades dans le groupe d'immigrants (non-compris les Européens) ont montré une hausse significative pendant les années 1952 à 1961 mais ont depuis diminué excepté chez les Asiatiques et les Européens. Cependant chez les deux sexes le nombre de cas chez les personnes nées au Royaume-Uni continue à augmenter.

(3) La plupart de l'augmentation de la blennorragie chez les hommes sont expliqués par la présence des immigrants. Il y a eu cependant une augmentation compatible et marquée chez les hommes nés au Royaume-Uni et même sans les immigrants il y aurait encore un problème qui va croissant.

(4) Un peu plus de quart des infections des hommes causées par la syphilis primaire et secondaire est importé tandis que pour la blennorragie la proportion est seulement d'un sur quinze; chez les femmes l'importation des deux maladies est relativement insignificante. Les immigrants dans le sens le plus large sont responsables d'un peu plus de la moitié des cas importés, mais il est probable qu'une large proportion de ceux-là soit en fait des marins. Les immigrants sont aussi responsables d'à peu près un tiers des cas de syphilis primaire et secondaire acquise au Royaume-Uni et excluant les Européens et d'autres groupes non-nègres la majorité des infections précoces sont contractées dans ce pays.

(5) Des femmes contacts connues des immigrants mâles souffrant de blennorragie à peu près la moitié se compose d'immigrantes et l'autre moitié est composée de femmes locales. Une tendance des partenaires d'être de la même race est remarquée. Cependant si seulement le foyer des contacts des Antillais est considéré presque six sur dix sont des femmes nées au Royaume-Uni.

(6) Les relevés suggèrent que l'incidence èlevée des maladies vénériennes chez les filles de 13 à 19 ans (âge tendre) n'est pas apparemment en relation directe au taux élevé chez les immigrants bien que les deux problèmes se chevauchent évidemment dans certaines régions. A St. Mary's pas moins de 41 pour cent des foyers d'infection des Antillais sont des filles de 13 a 19 ans (âge tendre).

(7) Le dépistage des contacts à Londres en questionnant les malades a apparemment autant de succès parmi les Antillais que parmi les autres groupes.

(8) L'homosexualité a apparu comme un facteur significatif dans l'épidemiologie des maladies vénériennes surtout dans le cas de la syphilis. Les relevés faits dans un dispensaire de Londres indiqueriait que la proportion des homosexuels avoués était presque cinq fois plus élevée chez les malades nés au Royaume-Uni que chez les immigrants, mais ce chiffre n'est peut-être pas exact.

(9) Les raisons sociales pour expliquer le taux élevé des maladies vénériennes chez les immigrants sont esquissées. La propagation des maladies vénériennes pourrait, peut-être, être empéchée en faisant venir des immigrantes ou par l'acceptation complète des groupes d'immigrants par la société - y compris toutes les implications - ou par un judicieux mélange de ces deux mesures. Cependant même si ces mesures étaient appliquées avec succès, le taux des maladies vénériennes parmi les immigrants ne pourrait tomber à peine au-dessous de celui de la population métropolitaine, et le taux parmi la population du Royaume-Uni est un problème qui va en augmentant. 